\title{
A bibliometric analysis of the global research on biosimilars
}

\author{
Akram Hernández-Vásquez ${ }^{1 *}$ (D), Christoper A. Alarcon-Ruiz², Guido Bendezu-Quispe ${ }^{3}$, Daniel Comandé ${ }^{4}$ \\ and Diego Rosselli ${ }^{5}$
}

\begin{abstract}
Background: Biosimilars could be a promising option to help decrease healthcare costs and expand access to treatment. There is no previous evidence of a global bibliometric analysis on biosimilars. Therefore, we aimed to assess the quantity and quality of worldwide biosimilars research.
\end{abstract}

Methods: We performed a bibliometric analysis using documents about biosimilars published until December 2016 in journals indexed in Scopus. We extracted the annual research, languages, countries, journals, authors, institutions, citation frequency, and the metrics of journals. The data were quantitatively and qualitatively analyzed using Microsoft Excel 2013. Additional information about authors' participation was obtained using the R-package Bibliometrix. Publication activity was adjusted for the countries by population size. Also, author co-citation analysis and a term co-occurrence analysis with the terms included in the title and abstract of publications was presented as network visualization maps using VOSviewer.

Results: A total of 2330 biosimilar-related documents identified in the Scopus database, most of them were articles (1452; 62.32\%). The number of documents published had an exponential increased between 2004 and 2016 ( $p<0.001)$. The United States was the country with the highest production with 685 (29.40\%) documents followed by Germany and UK with 293 (12.58\%) and 248 (10.64\%), respectively. Switzerland (11.05), Netherlands (5.85) and UK (3.83) showed the highest per capita ratio. The highest citation/article ratio were for the Netherlands (28.06), Spain (24.23), and France (20.11). Gabi Journal published 73 (3.13\%) documents; both Biopharm International and Pharmaceutical Technology and Mabs, 41 (1.76\%). Three out of top ten journals were Trade publications. Amgen Incorporated from the USA was the most prolific institution with 51 documents followed by Pfizer Inc. with 48. Terms about specific diseases and drugs were found in recent years, compared with terms such as legislation, structure, protein, dose and generic in the early years.

Conclusions: Research production and publication of documents on biosimilars are increasing. The majority of publications came from high-income countries. The trends in terminology use are according to state of the art in the topic, and reflects the interest in the utilization of biosimilars in diseases who are expected to obtain benefits of its use.

Keywords: Biosimilar pharmaceuticals, Bibliometrics, Biomedical research (source: MeSH NLM)

\section{Background}

A biosimilar, or "similar biological product", is a highly similar product to an already approved biological product regarding structure, function, potency, quality, clinical efficacy and safety [1]. Currently, there are already 5 and 39 biosimilars products approved in the United States [2] and Europe [3], respectively. The number of approved biosimilars might increase in the next

\footnotetext{
* Correspondence: akram.hernandez.v@upch.pe

'Universidad Privada del Norte, Lima, Peru

Full list of author information is available at the end of the article
}

year due to manifest interest from different healthcare systems and international organizations [4].

The development of biological products represented a significant advance in the therapy of many diseases that did not have effective treatments. Nonetheless, these products require a vast expenditure of money and resources to develop, leading to an increase in the cost of these therapies for both patients and the health sector $[5,6]$. The field of biosimilars could be a promising option to help decrease healthcare costs and expand access to treatment [7] particularly when many patents have already expired or will do so soon [8]. 
Few studies had evaluated the clinical evidence in support of different biosimilars: there are only three cancer related-biosimilars products whose safety/efficacy have been published [9], while five biosimilars for chronic inflammatory diseases have six clinical trials comparing them with their reference drug [10]. This situation of scarce evidence may lead physicians [11], pharmacists [12] and patients to have low confidence their safety and efficacy [13].

Bibliometric analysis is a useful method to objectively measure current research of a certain subject and its international scientific influence as an aspect of scientific quality [14]. However, to our knowledge, there is no previous evidence of a global bibliometric analysis on biosimilars. Our study aimed to assess the quantity and quality of worldwide biosimilars research.

\section{Methods}

\section{Study design}

We performed a bibliometric analysis using documents published until December 2016 in journals indexed in Scopus (https://www.scopus.com/). While there are a variety of document types, only articles, reviews, editorials and letters were included.

\section{Source of information}

Scopus (Elsevier BV Company, USA) is the largest abstract and citation database of scientific peer-review literature including more than 22,000 titles from international publishers. We decided to use this database because it includes all MEDLINE documents and includes further characteristics such as country of all the authors and citations per document, information that is relevant for this study [15-17].

\section{Search strategy}

A literature search was conducted by a research librarian in Scopus for publications on a single day, October 18, 2017, and used the following $\mathrm{MeSH}$ and free terms in the title and abstract field: biosimilar pharmaceutical OR biosimilar*. The validity of the search strategy was tested by manually reviewing retrieved articles.

\section{Data analysis}

All data were collected by two authors and downloaded in csv format (Additional file 1: Dataset). The data were imported to Microsoft Excel 2013 and quantitatively and qualitatively analyzed. The Scopus database presents some disadvantages for bibliometric applications [17]. For this reason, it was necessary to standardize the data. We detected documents mistakenly attributed to the domain of author name and affiliation. Therefore, a standardization was carried out manually by the authors.
Bibliometric indicators were extracted from the data and with the option "Analyze Results" in Scopus, including annual research, languages, countries, journals, authors, institutions, and citation frequency. Scopus Journal Metrics was used to extract the metrics of journals. The contributions of countries were evaluated based on paper and citation numbers, and the research output of each country was adjusted according to population size (https://www.cia.gov/library/ publications/the-world-factbook/geos/ag.html). To describe more information about author participation in research production about biosimilars, we use the open-source Bibliometrix R-package (http://www.bibliometrix.org/) to obtain the mean of articles per author, the mean of authors per article, the mean of articles' citation and the number of articles with only one or more than one author.

Author co-citation analysis (ACA) to analyze the relations among highly cited references and productive authors, and a term co-occurrence analysis with the terms included in the title and abstract of publications was presented as network visualization maps using VOSviewer version 1.6.6 (Leiden University, Leiden, Netherlands) techniques [18].

\section{Research ethics}

The data were downloaded from Scopus and as secondary data, did not involve any interactions with human subjects. There were no ethical questions about the data. Approval of an ethics committee was not necessary.

\section{Results}

A total number of 2330 documents indexed on Scopus were retrieved from 2004 to 2016 . The majority of papers were articles $(1452 ; 62.32 \%)$ followed by reviews (642; 27.55\%), editorials (138; 5.92\%), and letters (98; $4.21 \%)$. In 2004, three publications were identified compared to 521 in 2016 (Fig. 1); this increase in the amount of papers was statistically significant $(p<0.001)$. In general, 83 countries contributed to research articles about biosimilars. Table 1 listed the top ten countries, which represented $84.12 \%$ of the total. Seven of the top ten publishing countries are European. United States was the country with the highest production with 685 (29.40\%) documents followed by Germany and UK with $293(12.58 \%)$ and 248 (10.64\%), respectively. European countries such as Switzerland (11.05), Netherlands (5.85) and UK (3.83) showed the highest per capita ratio. The highest citation/article ratio were for the Netherlands (28.06), Spain (24.23), and France (20.11).

The analysis of the subject area, Table 2 shows that most documents were included in the broad category "Medicine" with 1453, followed by "Pharmacology, toxicology and pharmaceutics" with 946 and "Biochemistry, Genetics and Molecular biology" with 607. 


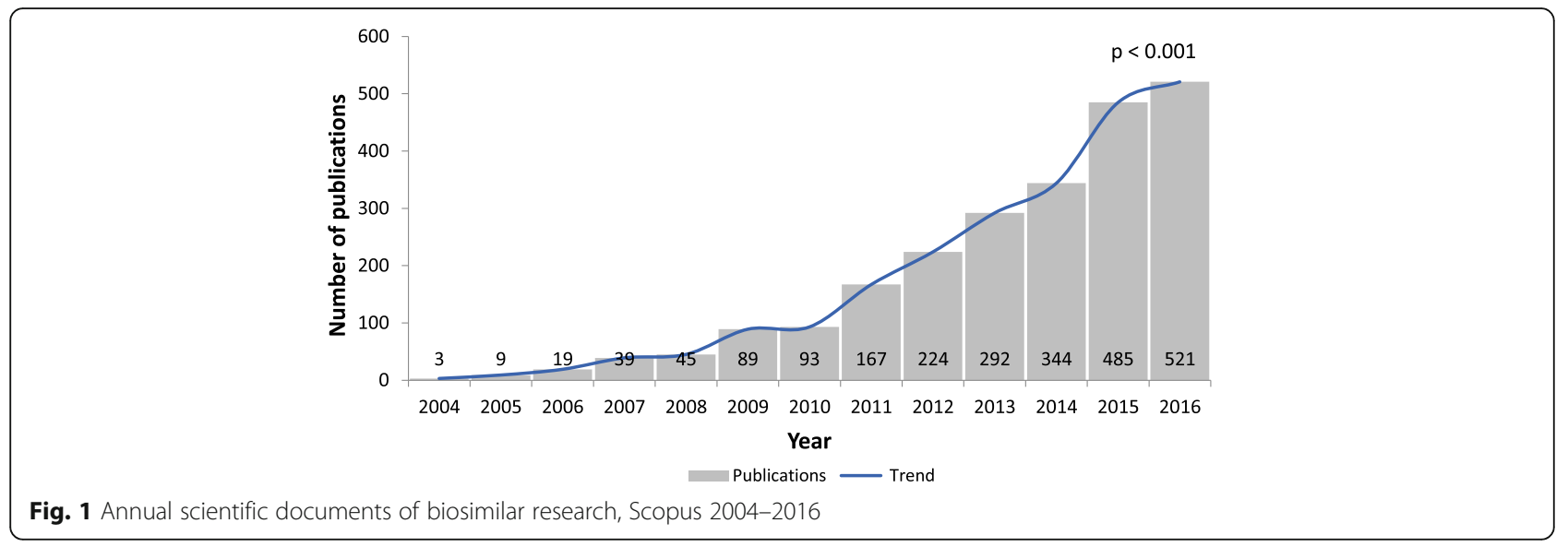

The total of documents retrieved were published in 803 journals, but top ten journals account for $18.82 \%$ of the total (Table 3). The top journals included in first place Gabi Journal with 73 (3.13\%) documents, followed by Biopharm International and Pharmaceutical Technology and Mabs both with 41 (1.76\%). Three out of ten titles were Trade publications. Mabs journal had the greatest SJR 2016 (1.62).

Table 4 presents a ranking of the Top ten institutions that published in biosimilars. Amgen Incorporated from the USA was the most prolific institution with 51 documents followed by Pfizer Inc. with 48. Seven of this top 10 list are European institutions, the others from USA. Four institutions were pharmaceutical companies. Based on the citations, academic institutions obtained higher positions compared to pharmaceutical companies being Medizinische Universitat Wien the institution with the highest number of citations and citations per articles ratio.

There were 6344 authors in the documents on biosimilars. The mean of articles per author was 0.4 and there were 420 documents with only one author. A co-authorship analysis that included authors with at least five publications is shown in Fig. 2. There were 143 authors; each circle represents one author, the closer the circles the closer the collaboration.
We show the top 10 cited articles in biosimilars in Table 5. The article "EULAR recommendations for the management of rheumatoid arthritis with synthetic and biological disease-modifying antirheumatic drugs: 2013 update" published in 2014 received the highest citation (962) within the retrieved documents. The top 10 include five articles and five reviews. All of the top ten cited articles were published in scientific journals. In general, the mean of citations per article was 9.6.

In the analysis of terms co-occurrence (Fig. 3), we used words in the titles and abstracts related to specific diseases and drugs. Rheumatoid arthritis, ulcerative colitis, rheumatism, infliximab, etanercept, and tofacitinib were found in recent years, compared with terms such as legislation, structure, protein, dose and generic in the early years.

\section{Discussion}

Biosimilars' cost-saving potential is their best attribute, making them an attractive option in the close future [19]. Also, the mandatory research that they have to do prior of their approval, and their large utility in diverse diseases, such as cancer, hemophilia, autoimmune diseases, and rare genetic conditions, make biosimilars an

Table 1 Top ten countries with more publications on biosimilars, and there average citation rate. Scopus 2004-2016

\begin{tabular}{|c|c|c|c|c|c|c|}
\hline Rank & Country & Number of documents & $\%$ of articles & Number of articles per million inhabitants & Citations (up 2016) & Citations/Article \\
\hline 1 & United States & 685 & 29.40 & 2.10 & 6768 & 9.88 \\
\hline 2 & Germany & 293 & 12.58 & 3.64 & 4373 & 14.92 \\
\hline 3 & United Kingdom & 248 & 10.64 & 3.83 & 3824 & 15.42 \\
\hline 4 & Italy & 149 & 6.39 & 2.40 & 2097 & 14.07 \\
\hline 5 & France & 132 & 5.67 & 2.10 & 2654 & 20.11 \\
\hline 6 & Netherlands & 100 & 4.29 & 5.85 & 2806 & 28.06 \\
\hline 7 & Spain & 91 & 3.91 & 1.86 & 2205 & 24.23 \\
\hline 8 & Switzerland & 91 & 3.91 & 11.05 & 1783 & 19.59 \\
\hline 9 & India & 86 & 3.69 & 0.07 & 338 & 3.93 \\
\hline 10 & Canada & 85 & 3.65 & 2.39 & 794 & 9.34 \\
\hline
\end{tabular}


Table 2 Subject areas for documents published on biosimilars, Scopus, 2004-2016

\begin{tabular}{llll}
\hline Rank & Subject area & $\begin{array}{l}\text { Documents } \\
\text { published }\end{array}$ & $\begin{array}{l}\text { \% of } \\
\text { documents }\end{array}$ \\
\hline 1 & Medicine & 1453 & 37.92 \\
2 & $\begin{array}{l}\text { Pharmacology, Toxicology and } \\
\text { Pharmaceutics }\end{array}$ & 946 & 24.69 \\
3 & $\begin{array}{l}\text { Biochemistry, Genetics and } \\
\text { Molecular Biology }\end{array}$ & 607 & 15.84 \\
4 & Immunology and Microbiology & 219 & 5.72 \\
5 & Health Professions & 165 & 4.31 \\
6 & Chemistry & 137 & 3.58 \\
7 & Chemical Engineering & 136 & 3.55 \\
8 & Business, Management and & 68 & 1.77 \\
9 & Accounting & & 1.62 \\
10 & Engineering & 62 & 1.02 \\
\hline
\end{tabular}

interesting field to make research. This explains the growing interest by many groups, including patients, health insurers, and providers, as well as the pharmaceutical industry. This interest is evidenced in the exponential increased of documents published on biosimilars between 2004 and 2016. High-income countries seem to dominate research in the field of biosimilars where the United States and Western European countries contributed to most of the world's research on biosimilars, and receive the most of the citations.

Authors from the United States published the highest number of scientific publications and received more citation compared to other countries. This result is not surprising, since the US leads the rankings in worldwide research, including medicine [20-22]. Majority of topranking countries were European. Although Switzerland, Netherlands, and United Kingdom do not have as many papers but go to the top of the list when we adjust by population. On the other hand, Netherlands, Spain, and France have the greatest citation per article. Those situations are similar in other biomedical fields: Rheumatology [20], arthroscopy [23], foot and ankle [24], and probiotics in pediatrics [25], but it differs from endocrinology and metabolism field [26] and research on tramadol [27]. It would perhaps be better to adjust by the number of researchers, instead of inhabitants, but this information is not easily accessible [26].

"Gabi Journal" and "Mabs" were the most productive peer-review journals in the topic of biosimilars. Besides, "Biopharm International", a trade publication journal, occupied the second most productive journal on biosimilars. It is remarkable that three trade publication journals, perhaps showing the industry's interest in promoting their products, were in the top 10 most productive journals, but they do not receive that many citations. This may reflect the fact that they might be considered less trustful, or that they are not necessarily targeted at researchers [28]. Both "Mabs" and "Expert Opinion on Biological Therapy" are rated much higher in CiteScore 2017, SJR 2016, and SNIP 2016, despite having less publications. These suggest that at least in the field of biosimilars quantity is not necessarily correlated with quality. This situation differs from other biomedical fields like spine surgery [29].

Only three of the top 10 institutions were from America, the other seven were from Europe. This reflects the fact that biosimilars are a subject of interest in many different countries. Additionally, institutions with most citations and mean citation rate were from universities, which might indicate its better quality. Also, there is less risk that universities have conflicts of interest in developing research papers in biosimilars, so their results might be more trustful.

The top five most cited papers were original articles. The top two were guidelines for management of clinical conditions (rheumatoid arthritis and febrile neutropenia). This could be explained because three biosimilars are available to treat rheumatoid arthritis and others are in the way to approval [30], and the recent

Table 3 Top ten journals publishing on biosimilars ( $N=2330$ ). Scopus 2004-2016

\begin{tabular}{|c|c|c|c|c|c|c|c|}
\hline Rank & Source title & Publication type & Documents published & $\%$ of articles & CiteScore 2016 & SJR 2016 & SNIP 2016 \\
\hline 1 & Gabi Journal & Journal & 73 & 3.13 & 0.28 & 0.23 & 0.08 \\
\hline 2 & Biopharm International & Trade Publication & 41 & 1.76 & 0.17 & 0.16 & 0.08 \\
\hline 3 & Mabs & Journal & 41 & 1.76 & 4.66 & 1.62 & 1.25 \\
\hline 4 & Biodrugs & Journal & 40 & 1.72 & 2.98 & 1.01 & 1.13 \\
\hline 5 & Bioprocess International & Trade Publication & 39 & 1.67 & 0.26 & 0.23 & 0.25 \\
\hline 6 & Pharmaceutical Technology & Journal & 39 & 1.67 & 0.09 & 0.14 & 0.16 \\
\hline 7 & Biologicals & Journal & 34 & 1.46 & 1.65 & 0.62 & 0.74 \\
\hline 8 & Contract Pharma & Trade Publication & 30 & 1.29 & 0.02 & 0.12 & 0 \\
\hline 9 & Journal of Generic Medicines & Journal & 28 & 1.20 & 0.12 & 0.14 & 0.39 \\
\hline 10 & Expert Opinion on Biological Therapy & Journal & 27 & 1.16 & 3.14 & 1.14 & 0.75 \\
\hline
\end{tabular}


Table 4 Top ten institutions publishing on biosimilars, and their citations. Scopus 2004-2016

\begin{tabular}{llllll}
\hline Rank & Institution Name & Country & Number of papers & Citations & Citations/Article \\
\hline 1 & Amgen Incorporated & United States & 51 & 394 & 7.73 \\
2 & Pfizer Inc. & United States & 48 & 201 & 4.19 \\
3 & Utrecht University & Netherlands & 44 & 898 & 20.41 \\
4 & Duke University & United States & 37 & 763 & 20.62 \\
5 & Sandoz International GmbH & Germany & 33 & 460 & 13.94 \\
6 & Medizinische Universitat Wien & Austria & 23 & 1538 & 66.87 \\
7 & KU Leuven & Belgium & 22 & 227 & 10.32 \\
8 & Erasmus University Medical Center & Netherlands & 20 & 929 & 46.45 \\
9 & Universita degli Studi di Milano & Italy & 20 & 152 & 7.6 \\
10 & Novartis International AG & Switzerland & 19 & 174 & 9. \\
\hline
\end{tabular}

approval process of granulocyte-colony stimulating factor biosimilars, a useful drug to treat febrile neutropenia [31]. Moreover, clinical practice guidelines from any field generally have a lot of cites. The fourth and fifth most cited articles were randomized controlled clinical trials of the infliximab biosimilar CT-P13. This is the first biosimilar monoclonal antibody approved by the European Medicines Agency [32]. Overall, those two clinical trials help to understand and accept their interchangeability with infliximab as a feasible and safe strategy to be applied in real-life clinical practice [33]. On the other side, there were five reviews in the top 10 .
Mostly, they try to better explain biosimilars to health professionals, especially clinician [34], that could have some reluctance about the use of biosimilars [35]. These reviews focus on improving the uptake of biosimilars, educating the physicians, and motivating to adopt them in routine clinical practice [36].

Words included in the title and abstracts of biosimilars research papers and their main year when they were published were: Legislation (2011), enzyme (2012), structure, protein, dose, antibody, interchangeability (2013), glycosylation, receptor, phase, adverse event (2014), and rheumatoid arthritis, ulcerative colitis,

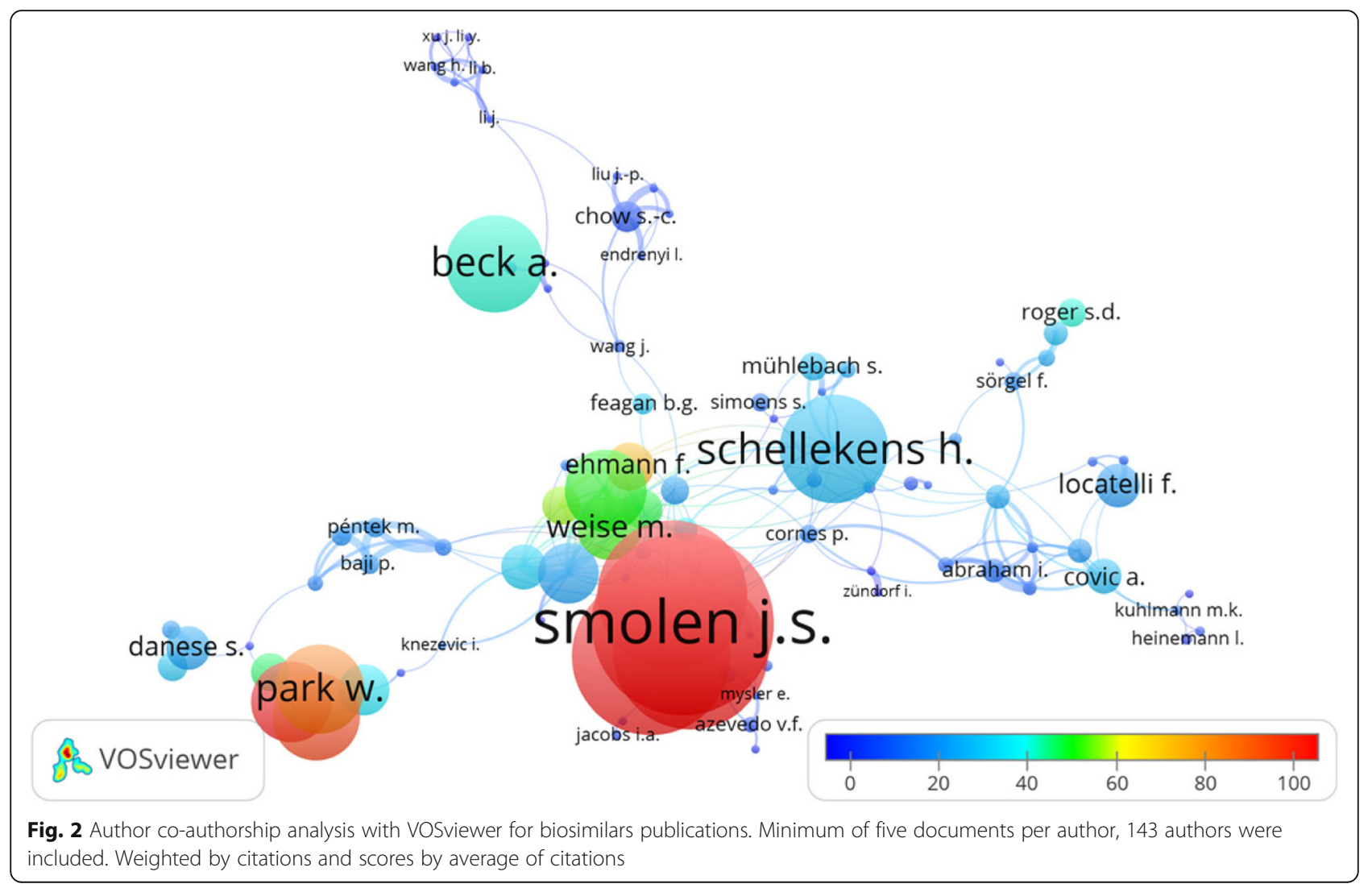


Table 5 Top 10 cited documents of biosimilars research. Scopus 2004-2016

\begin{tabular}{|c|c|c|c|c|c|}
\hline Rank & Title & Year & Journal name & Cited by & $\begin{array}{l}\text { Type of } \\
\text { documen }\end{array}$ \\
\hline 1 & $\begin{array}{l}\text { EULAR recommendations for the management of rheumatoid arthritis } \\
\text { with synthetic and biological disease-modifying antirheumatic drugs: } 2013 \text { update }\end{array}$ & 2014 & $\begin{array}{l}\text { Annals of the } \\
\text { Rheumatic Diseases }\end{array}$ & 962 & Article \\
\hline 2 & $\begin{array}{l}2010 \text { update of EORTC guidelines for the use of granulocyte-colony stimulating } \\
\text { factor to reduce the incidence of chemotherapy-induced febrile neutropenia in } \\
\text { adult patients with lymphoproliferative disorders and solid tumours }\end{array}$ & 2011 & $\begin{array}{l}\text { European Journal } \\
\text { of Cancer }\end{array}$ & 498 & Article \\
\hline 3 & Biopharmaceutical benchmarks 2014 & 2014 & Nature Biotechnology & 275 & Article \\
\hline 4 & $\begin{array}{l}\text { A randomised, double-blind, parallel-group study to demonstrate equivalence in } \\
\text { efficacy and safety of CT-P13 compared with innovator infliximab when coadministered } \\
\text { with methotrexate in patients with active rheumatoid arthritis: The PLANETRA study }\end{array}$ & 2013 & $\begin{array}{l}\text { Annals of the } \\
\text { Rheumatic Diseases }\end{array}$ & 269 & Article \\
\hline 5 & $\begin{array}{l}\text { A randomised, double-blind, multicentre, parallel-group, prospective study } \\
\text { comparing the pharmacokinetics, safety, and efficacy of CT-P13 and innovator } \\
\text { infliximab in patients with ankylosing spondylitis: The PLANETAS study }\end{array}$ & 2013 & $\begin{array}{l}\text { Annals of the } \\
\text { Rheumatic Diseases }\end{array}$ & 250 & Article \\
\hline 6 & $\begin{array}{l}\text { Analytical tools for characterizing biopharmaceuticals and the implications } \\
\text { for biosimilars }\end{array}$ & 2012 & $\begin{array}{l}\text { Nature Reviews Drug } \\
\text { Discovery }\end{array}$ & 215 & Review \\
\hline 7 & PEG-modified biopharmaceuticals & 2009 & $\begin{array}{l}\text { Expert Opinion on } \\
\text { Drug Delivery }\end{array}$ & 201 & Review \\
\hline 8 & The challenge of biosimilars & 2008 & Annals of Oncology & 178 & Review \\
\hline 9 & Sublingual immunotherapy: World Allergy Organization position paper 2013 update & 2014 & $\begin{array}{l}\text { World Allergy } \\
\text { Organization Journal }\end{array}$ & 172 & Review \\
\hline 10 & Biosimilars: What clinicians should know & 2012 & Blood & 158 & Review \\
\hline
\end{tabular}

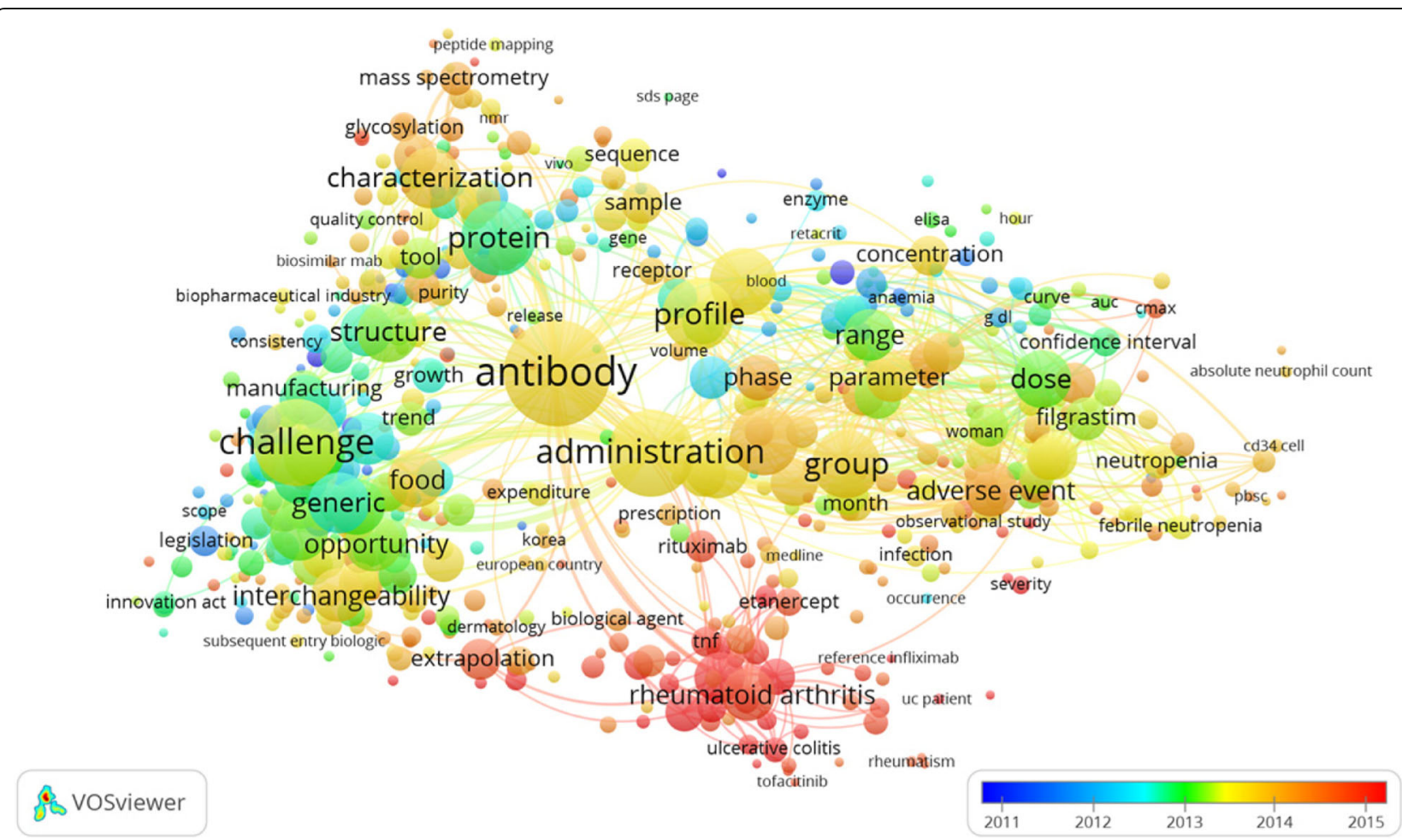

Fig. 3 Terms co-occurrence analysis of tittles and abstracts (overlay visualization) and their temporal evolution with VOSviewer for biosimilars publications. Binary counting method, choose threshold (10 terms). Term "conclusion" was excluded 
extrapolation, rituximab, etanercept (2015). This suggests that the emphasis of biosimilars research responds to a subject that is very new to researchers and should follow the law of the development of a new discipline. This find is similar to a report in a previous bibliometric analysis on exomes [37]. In the field of biosimilars, there are requirements for their approval, including to demonstrate similarity, safety, and effectiveness [38]. These terms were more frequently found in the early.

The present research shows an overall view about biosimilars research and their distribution mostly in high-income countries where they have policies to their approval. Although markets like BRICS (Brazil, Russia, India, China, and South Africa), MIST (Mexico, Indonesia, South Korea, and Turkey) [39], and Latin America [40] provides an emerging future to biosimilars, they do not represent an important influence in biosimilars research. Also, the present study like previous bibliometric analyses has some limitations. First, our study did not include articles published in nonScopus databases. However, Scopus is a reliable and significant source for bibliometric studies in general. Second, it is difficult to distinguish articles that focus on biosimilars from those that only mention the term or tangentially address it. However, using correct keywords and given its original subject, this study still provides a comprehensive picture of biosimilar research productivity, which could be used to track overall trends and identify topics of interest.

\section{Conclusions}

In summary, the results of the present study showed that documents published in journals about biosimilars are increasing. The majority of publications came from high-income countries, being the US the most productive country in biosimilars followed by European countries. To the best of our knowledge, this is the first study conducted in the analysis of research production and citations in biosimilars. The trends in terminology use are according to state of the art in the topic that comes from issues of safety and efficacy to the study of new biosimilar products in specific diseases.

\section{Additional file}

Additional file 1: Dataset 1: Data obtained from Scopus, a .CSV that contain list of studies included. (CSV $6323 \mathrm{~kb}$ )

\section{Abbreviations}

MeSH: Medical subject heading; SNIP: SCImago journal rank; SR: Source normalised impact per paper; UK: United Kingdom; USA: United States of America

\section{Funding}

This research received no specific grant from any funding agency.

\section{Availability of data and materials}

All data analyzed in this study is included in Dataset 1: Data obtained from Scopus, a. CSV that contain list of studies included.

\section{Authors' contributions}

AHV conceived the idea for the study; AHV and DC collected the data; AHV and GBQ did the statistical analysis; AHV, GBQ, CAAR and DR drafted the manuscript; all authors contributed in the writing and preparation of the manuscript. All authors read and approved the final manuscript.

\section{Ethics approval and consent to participate}

This study did not require the approval of an ethics committee as it is a secondary analysis of a database of a public domain and of free access.

\section{Consent for publication}

This study did not require consent for publication.

\section{Competing interests}

The authors declare that they have no competing interests.

\section{Publisher's Note}

Springer Nature remains neutral with regard to jurisdictional claims in published maps and institutional affiliations.

\section{Author details}

${ }^{1}$ Universidad Privada del Norte, Lima, Peru. ${ }^{2}$ Facultad de Medicina, Universidad Ricardo Palma, Lima, Peru. ${ }^{3}$ Universidad Peruana Cayetano Heredia, Lima, Peru. ${ }^{4}$ Institute for Clinical Effectiveness and Health Policy (IECS), Buenos Aires, Argentina. ${ }^{5}$ Departamento de Epidemiología Clínica y Bioestadística, Facultad de Medicina, Pontificia Universidad Javeriana, Bogotá, Colombia.

Received: 20 November 2017 Accepted: 5 March 2018

Published online: 27 March 2018

\section{References}

1. Declerck P, Danesi R, Petersel D, Jacobs I. The language of Biosimilars: clarification, definitions, and regulatory aspects. Drugs. 2017;77(6):671-7.

2. US Food and Drug Administration. Purple Book: Lists of Licensed Biological. US Department of Health and Human Services, Food and Drug Administration, Center for Biologics Evaluation and Research (CBER). 2017 [cited 2017 August 13]. Available from: https://www.fda.gov/downloads/ Drugs/DevelopmentApprovalProcess/HowDrugsareDevelopedandApproved/ ApprovalApplications/TherapeuticBiologicApplications/Biosimilars/ UCM560162.pdf.

3. Biosimilars approved in Europe. Generics and Biosimilars Initiative July 7, 2017 [cited 2017 August 13]. Available from: http://www.gabionline.net/ Biosimilars/General/Biosimilars-approved-in-Europe.

4. Bennett S. WHO to begin pilot prequalification of biosimilars for cancer treatment. 2017 [cited 2017 November 05]. Gineva: World Health Organization; [Nov 05, 2017]. Available from: http://www.who.int/ mediacentre/news/releases/2017/pilot-prequalification-biosimilars/en/.

5. Blackstone E, Fuhr J. Innovation and competition: will biosimilars succeed? Biotechnol Healthcare. 2012;9(1):24-7.

6. Prince FH, van Suijlekom-Smit LW. Cost of biologics in the treatment of juvenile idiopathic arthritis: a factor not to be overlooked. Paediatr Drugs. 2013;15(4):271-80

7. Boccia R, Jacobs I, Popovian R, de Lima LG, Jr. Can biosimilars help achieve the goals of US health care reform? Cancer Manag Res. 2017;9:197-205.

8. Ventola CL. Biosimilars. Part 1: proposed regulatory criteria for FDA approval. P T. 2013;38(5):270-4. 277, 287

9. Jacobs I, Ewesuedo R, Lula S, Zacharchuk C. Biosimilars for the treatment of Cancer: a systematic review of published evidence. BioDrugs. 2017;31(1):1-36

10. Olteanu R, Zota A, Constantin M. Biosimilars: an update on clinical trials (review of published and ongoing studies). Acta Dermatovenerol Croat. 2017;25(1):57-66.

11. Cohen H, Beydoun D, Chien D, Lessor T, McCabe D, Muenzberg M, et al Awareness, knowledge, and perceptions of Biosimilars among specialty physicians. Adv Ther. 2017;33(12):2160-72. 
12. Beck M, Michel B, Rybarczyk-Vigouret MC, Leveque D, Sordet C, Sibilia J, et al. Knowledge, behaviors and practices of community and hospital pharmacists towards biosimilar medicines: results of a French webbased survey. MAbs. 2017:9(2):383-90.

13. Jacobs I, Singh E, Sewell KL, Al-Sabbagh A, Shane LG. Patient attitudes and understanding about biosimilars: an international cross-sectional survey. Patient Preference Adherence. 2016;10:937-48.

14. Van Raan T. The use of bibliometric analysis in research performance assessment and monitoring of interdisciplinary scientific developments. Technikfolgenabschautzung - Theorie und Praxis. 2003;1:20-9.

15. Falagas ME, Pitsouni El, Malietzis GA, Pappas G. Comparison of PubMed, Scopus, web of science, and Google scholar: strengths and weaknesses. FASEB J. 2008;22(2):338-42

16. Kulkarni AV, Aziz B, Shams I, Busse JW. Comparisons of citations in web of science, Scopus, and Google scholar for articles published in general medical journals. JAMA. 2009;302(10):1092-6.

17. Agarwal A, Durairajanayagam D, Tatagari S, Esteves SC, Harlev A, Henkel R, et al. Bibliometrics: tracking research impact by selecting the appropriate metrics. Asian J Androl. 2016;18(2):296-309.

18. van Eck NJ, Waltman L. Software survey: VOSviewer, a computer program for bibliometric mapping. Scientometrics. 2010;84(2):523-38.

19. Nabhan C, Parsad S, Mato AR, Feinberg BA. Biosimilars in oncology in the United States: a review. JAMA Oncol. 2017:4(2):241-7.

20. Cheng T, Zhang G. Worldwide research productivity in the field of rheumatology from 1996 to 2010: a bibliometric analysis. Rheumatology. 2013;52(9):1630-4.

21. Li Q, Jiang $Y$, Zhang M. National representation in the emergency medicine literature: a bibliometric analysis of highly cited journals. Am J Emerg Med. 2012;30(8):1530-4.

22. Zhang WJ, Ding W, Jiang H, Zhang YF, Zhang JL. National representation in the plastic and reconstructive surgery literature: a bibliometric analysis of highly cited journals. Ann Plast Surg. 2013;70(2):231-4.

23. Liang Z, Luo X, Gong F, Bao H, Qian H, Jia Z, et al. Worldwide research productivity in the field of arthroscopy: a bibliometric analysis. Arthroscopy. 2015;31(8):1452-7

24. Luo X, Liang Z, Gong F, Bao H, Huang L, Jia Z. Worldwide productivity in the field of foot and ankle research from 2009-2013: a bibliometric analysis of highly cited journals. J Foot Ankle Res. 2015;8:12.

25. Sweileh WM, Shraim NY, Al-Jabi SW, Sawalha AF, Rahhal B, Khayyat RA, et al. Assessing worldwide research activity on probiotics in pediatrics using Scopus database: 1994-2014. World Allergy Organ J. 2016;9:25.

26. Zhao X, Ye R, Zhao L, Lin Y, Huang W, He X, et al. Worldwide research productivity in the field of endocrinology and metabolism-a bibliometric analysis. Endokrynologia Polska. 2015;66(5):434-42.

27. Sweileh WM, Shraim NY, Zyoud SH, Al-Jabi SW. Worldwide research productivity on tramadol: a bibliometric analysis. SpringerPlus. 2016;5(1):1108

28. Oklahoma State University. Article Types and indentification: Trade Publications [Internet]. Oklahoma: Oklahoma State University, Library; 2016 [cited 2017 Sep 23]. [Available from: info.library.okstate.edu/c. php?g=151701\&p=998800

29. Wei M, Wang W, Zhuang Y. Worldwide research productivity in the field of spine surgery: a 10-year bibliometric analysis. Eur Spine J. 2016;25(4):976-82.

30. Rein P, Mueller RB. Treatment with biologicals in rheumatoid arthritis: an overview. Rheumatol Ther. 2017;4(2):247-61.

31. Schulz $\mathrm{M}$, Bonig $\mathrm{H}$. Update on biosimilars of granulocyte colony-stimulating factor - when no news is good news. Curr Opin Hematol. 2016;23(1):61-6.

32. McKeage K. A review of CT-P13: an infliximab biosimilar. BioDrugs. 2014; 28(3):313-21.

33. Becciolini A, Raimondo MG, Crotti C, Agape E, Biggioggero M, Favalli EG. A review of the literature analyzing benefits and concerns of infliximab biosimilar CT-P13 for the treatment of rheumatologic diseases: focus on interchangeability. Drug Des, Dev Ther. 2017;11:1969-78.

34. Eleryan MG, Akhiyat S, Rengifo-Pardo M, Ehrlich A. Biosimilars: potential implications for clinicians. Clin Cosmet Investig Dermatol. 2016:9:135-42.

35. van Overbeeke E, De Beleyr B, de Hoon J, Westhovens R, Huys I. Perception of originator biologics and Biosimilars: a survey among Belgian rheumatoid arthritis patients and rheumatologists. BioDrugs. 2017;31(5):447-59.

36. Gyawali B. Biosimilars in oncology: everybody agrees but nobody uses? Recenti Prog Med. 2017;108(4):172-4.
37. Wang Y, Wang Q, Wei X, Shao J, Zhao J, Zhang Z, et al. Global scientific trends on exosome research during 2007-2016: a bibliometric analysis. Oncotarget. 2017:8(29):48460-70.

38. Sullivan PM, DiGrazia LM. Analytic characterization of biosimilars. Am J Health Syst. 2017;74(8):568-79.

39. Farhat F, Torres A, Park W, de Lima LG, Mudad R, Ikpeazu C, et al. The concept of Biosimilars: from characterization to evolution-a narrative review. Oncologist. 2017;22:1-7.

40. Garcia R, Araujo DV. The regulation of Biosimilars in Latin America. Curr Rheumatol Rep. 2016;18(3):16.

\section{Submit your next manuscript to BioMed Central and we will help you at every step:}

- We accept pre-submission inquiries

- Our selector tool helps you to find the most relevant journal

- We provide round the clock customer support

- Convenient online submission

- Thorough peer review

- Inclusion in PubMed and all major indexing services

- Maximum visibility for your research

Submit your manuscript at www.biomedcentral.com/submit
Biomed Central 